Saudi Journal of Economics and Finance

Abbreviated Key Title: Saudi J Econ Fin ISSN 2523-9414 (Print) |ISSN 2523-6563 (Online) Scholars Middle East Publishers, Dubai, United Arab Emirates Journal homepage: http://saudijournals.com/sjef/

Original Research Article

\title{
Evaluation of Village Device Selection in Handil Babirik Village and Tajau Pecah Village, Tanah Laut Regency
}

Muhammad Hadiat Wicaksono ${ }^{*}$, Asmaji Darmawi, Jamaluddin

Master Program of Government Science, Lambung Mangkurat University, Banjarmasin, Indonesia

\author{
DOI: $10.36348 /$ sjef.2019.v03i11.007 $\quad$ | Received: 09.11.2019| Accepted: 15.11.2019| Published: 19.11 .2019 \\ *Corresponding author: Muhammad Hadiat Wicaksono
}

\section{Abstract}

The objective of this study is to improve the recruitment system of village apparatus by analyzing and evaluating the public service selection in those village jurisdictions. This study uses qualitative method with descriptive approach. The respondents are the heads of local sub-district, officers in Village Community Development Office (DPMD) of Tanah Laut Regency, authorized officers and elements of community related to the selection. In data analysis, Strength, Weakness, Opportunity, Threat (SWOT) approach are adopted. The results point out that the public service selections in those locus are following the existing guidelines and regulation. However, there are practices that are not conformed with current regulation and the expectation. From the perspective of village apparatus/human resources, the incompliance are the infirmity of administration, and Tajau Pecah residents understanding of decision taken associated with village apparatus selection is better than Handil Babirik occupants. From organization point of view, there are the difference of regulation interpretation between the stakeholders, low transparency of information and insemination to the village society. Moreover from the angel of regulation implementation, skills and competency are not accommodated in the determination of the selection result through relevant recruitment test.

Keywords: Evaluation, selection, village officials, regulation, swot analysis.

Copyright @ 2019: This is an open-access article distributed under the terms of the Creative Commons Attribution license which permits unrestricted use, distribution, and reproduction in any medium for non-commercial use (NonCommercial, or CC-BY-NC) provided the original author and source are credited.

\section{INTRODUCTION}

Basically, the Government hopes that with the new regulation it is expected to be able to screen and screen qualified and competent village apparatus and avoid KKN behavior (Corruption, Collusion, and Nepotism), but in its implementation there are indications that cause a lack of screening and screening. quality and smell of KKN [1]. This is not much different from past patterns that still have not completely disappeared from the mindset of stakeholders. Whereas with recruitment in accordance with regulations, qualified and competent village officials will be screened to support the implementation of government and village development tasks, especially now that the village enjoys a substantial development fund. This of course must be managed professionally by the village head and village apparatus, so that a sufficiently large amount of funds can be used effectively and efficiently [2].

Some problems related to the selection of village officials that have been described above, become a question of how the actual flow of the selection process for village apparatus candidates carried out by the Village Government, and what are the problems [3]. These problems are the lack of information disclosure and the lack of explanation regarding the applicable regulations related to the selection of village officials. It should also be noted that the work of village officials is currently very promising, bearing in mind that village officials who have passed have a fixed income per month and the work system is similar to that of Civil Servants / State Civil Servants with retirement age determined in the Act. So that there are no worries about being laid off as long as the person concerned does not violate the rules. So it cannot be denied that competition in the village apparatus selection is quite tight, as happened in North Kurau Village and Bajuin District. Regarding the selection of village apparatuses, it is necessary to have an evaluation where the results of the evaluation will be known to what extent the implementation of the village apparatus selection is applied and also to find out things that are still a weakness in its implementation that has the potential to cause problems. So with a focus on evaluating village apparatus selection, it will outline problems related to village apparatus selection in Tanah Laut Regency. 
Based on these problems, the researcher becomes the basis for studying, researching, and compiling a thesis entitled "Evaluation of Village Apparatus Selection in Handil Babirik Village, Bumi Makmur District and Tajau Pecah Village, Batu Ampar District, Tanah Laut Regency". The reason the researchers took the data in Handil Babirik Village is because this village is a homogeneous village. Homogeneity is meant in the sense that the majority of the population is people who have the same ethnicity / race, language, and culture. In addition, Handil Babirik Village is the first village in Bumi Makmur Subdistrict to have completed the process of appointing village officials in accordance with the latest village regulations. Therefore, an evaluation study on the arrangement of village officials is important to be done in Handil Babirik Village as an illustration for other villages in Bumi Makmur Subdistrict. While the reason the researchers took the data in the village of Tajau Pecah was because the village was a heterogeneous village and had a fairly complete administration. The heterogeneous population is defined as a group of people from various ethnic / racial, social levels, languages, dialects and diverse cultures. Tajau Pecah Village is expected to be a comparison to Handil Babirik Village in terms of the implementation of the village apparatus selection.

This article aims to conduct an evaluation based on the implementing regulations in the Tanah Laut Regency Government, namely Regulations of the Tanah Laut Regent Number 6 of 2016 concerning Appointment and Dismissal of Village Apparatus, because the object of study is the autonomous region of Tanah Laut Regency, whereas if the researcher evaluates the articles related to selection Village apparatus in Law Number 6 of 2014 concerning Village objects that must be examined is not only the scope of Tanah Laut Regency but must examine several objects outside Tanah Laut District and South Kalimantan Province. This is considered quite difficult to conduct the research in terms of distance, time, cost, and other technical matters.

\section{METHODS}

The type of research approach used is a qualitative approach because in research like this everything can happen and cannot be predicted in advance. It is rather difficult to ensure everything is in accordance with the calculations due to various dynamics and developments that occur in the field. So with a qualitative approach to obtain facts and conclusions that are more accurate [6]. The research location in this thesis is located in Handil Babirik Village, Bumi Makmur District and Tajau Pecah Village, Batu Ampar District, Tanah Laut Regency. Information relating to the evaluation of village apparatus selection in Handil Babirik Village, Bumi
Makmur Subdistrict and Tajau Pecah Village, Batu Ampar District, Tanah Laut District, needed information from informants. The informants included:

1. Bumi Makmur District Chief

2. Batu Ampar District Chief

3. Official at the Tanah Laut Regency Community and Village Empowerment Office

4. Head of Governance Section in Bumi Makmur District

5. Head of Governance Section in Batu Ampar District

6. Head of Handil Babirik Village

7. Tajau Pecah Village Head

8. Former Handil Babirik Village Apparatus, one respondent

9. Former Tajau Pecah Village Apparatus, one respondent

10. Handil Babirik Village Apparatus, two respondent

11. Tajau Pecah Village Apparatus, one respondent

12. Handil Babirik Village Candidate Selection Committee, one respondent

13. Tajau Broke Village Candidate Selection Committee, one respondent

14. Handil Babirik Village community protested, two respondents

15. Tajau Pecah Village community protested, one respondent

16. Handil Babirik Village people agreed, one respondent

17. Tajau Pecah Village people agreed, one respondent

Data collection is the most important element in carrying out scientific research. Therefore data collection must be carried out seriously so that it is relevant to the topic of discussion. Data collection techniques used: 1) Observation Involved, 2) Interviews, and 3) Documentation/Literature [4]. Data analysis techniques were performed using SWOT Analysis. The first step taken is to identify 2 (two) categories of analysis conclusions to be the Internal Factor Analysis Conclusion (KAFI) and the Conclusion of External Factor Analysis (KAFE) on the research data collected from Handil Babirik and Tajau Pecah Villages. The second step is to include KAFI and KAFE in the SWOT matrix approach. This is done to combine strengths and weaknesses with opportunities and threats to determine alternative organizational strategies for evaluating the selection of village officials carried out in Handil Babirik and Tajau Pecah Villages [5, 6].

\section{RESULTS AND DISCUSSION}

The phenomenon of decentralization in Indonesia is interesting to observe, especially related to the behavior of bureaucratic KKN in the regions. The 
closeness between the locus of power and citizens does not guarantee the effectiveness of control over the use of power. When power is transferred in the area one of the assumptions is that power will guarantee that it will be easier to control because citizens will be easier to participate in decision making [7]. Citizens will also find it easier to control and supervise the practice of the use of power because the use of power becomes easier to observe and criticize when values are not in line with the expectations of citizens or the prevailing norms.

It turns out that without transparency, the assumptions mentioned above tend not to apply. What happened in the regions proves that decentralization will not be able to suppress $\mathrm{KKN}$ practices in the regions without transparency. The involvement of third parties makes the village community confident of the openness of the recruitment system where they can immediately know the results of the selection and can immediately feel the atmosphere of a fair selection process without the presence of certain parties who try to influence the final results. Transparency in the process of filling village officials raises public trust in the village government. Community trust is an indicator of the principle of accountability of the village government itself. Increased public confidences, reduced cases of collusion and nepotism that wrap the process of filling village officials by basing themselves on previous regulations, are also indicators of the principle of accountability.

Various important information in the process of village apparatus selection. The various information will be discussed using SWOT Analysis (Strength, Weakness, Opportunity, Threat). SWOT is an analysis of internal factors and external factors that use data or information in the form of Strengths, Weaknesses, Opportunities, and Threats. With this analysis, it is hoped that it can explain the results of the evaluation of the implementation of the village apparatus selection in Tanah Laut Regency. Next will be explained further. SWOT analysis related to the process of village apparatus selection in Handil Babirik Village, Bumi Makmur Subdistrict as follows.

\section{Conclusion of Internal Factor Analysis (KAFI)}

Is a factor that comes from within consists of 2 (two), namely Strength (Strength) and Weakness (Weakness). Logically, both will have a better impact in a study when strength is greater than weakness. Thus the maximum internal strength will clearly provide much better research results. As for the internal factors, these include resources owned, financial, internal strengths or weaknesses of the organization, and previous organizational experience of both successes and failures.

\section{Strength}

a. There is a Demand to Increase the Professionalism of Village Apparatus in Supporting the
Performance of Village Heads and Village Government

This is based on the mandate of Law No. 6 of 2014 concerning Villages, namely the expectations of the government and the village community so that village services and development are faster and improved. The law is a basic rule for village administration.

\section{b. Clear Competency Standards To Become Village Officials}

Pursuant to Law Number 6 of 2014 concerning Villages, the competency standard referred to is the minimum education of village apparatus must be high school or equivalent, registered as a resident of the village and residing in the village at least 1 (one) year before registration, aged 20 (twenty) years up to 42 (forty two) years to be appointed as an instrument, other conditions stated in the district regulation.

c. The formation of the Selection and Screening Team for Village Candidates

The Village Head has formed a screening and screening team by issuing a Village Head Decree. This becomes the main basis in carrying out all the activities of selecting and selecting or selecting village officials.

d. Coordination and Consultation from the Village Head to the Disyrict Chief

The Village Head has coordinated and consulted with the District Chief in carrying out the selection and selection or selection of village officials. This means that the Village Head has understood and knows the stages of the mechanism.

\section{Weakness}

1. Lack of Understanding and Compliance with Village Heads and Stakeholders Involved in Regulations in the Selection of Village Officials

This is evidenced by the filling of the screening and screening teams or committees that have not accommodated village community leaders and social institutions. Besides that, related to how to fill out the empty device formation, the candidate of the village apparatus should apply when applying directly to the desired formation, for example the formation of the Village Secretary or Head of Affairs.

\section{Lack of Order and Weak Village Government Administration}

This can be seen from the length of the letter process that should have been followed up immediately and the inconsistency in the use of the screening and screening team names and the screening and screening committee in documents or letters made by the village. In addition, there was a letter from the Village Head similar but with a different date that entered the Bumi Makmur Subdistrict. 
3. Lack of Information on the Selection and Screening of Candidates for Village Officials and Socialization of the Appointment of Village Apparatus to Local Residents

The village community stated that the Village Head did not disseminate information on the selection and screening of the Handil Babirik Village apparatus.

As stated in the selection theory sub-chapter in the conditions of applicant bidding the more the number of prospective employees who meet the qualifications (qualified), it will be easier for institutions / institutions/bodies to get employees who have quality and vice versa. At the time of recruitment, there may be a smaller number of applicants who are netted than expected. This situation might occur if there is a lack of information on the selection and screening of village instruments received by job seekers in the village.

4. There Is An Effort From The Village Head To Pass Supporters And Their Families In The Selection Of Village Apparatus

This was confirmed by the community who stated that many supporters and families of Village Heads were appointed as village apparatus as a result of screening and screening.

As also stated in the selection theory subchapter in organizational external factors, there are ethical factors, namely at the selection stage, ethical matters are usually a formidable challenge. Selection results are usually influenced by ethical decisionmaking factors. If the consideration of acceptance is more directed by the relationship of relatives, friends, giving money/goods rather than consideration of competence/skills, then most likely the employee received are not in accordance with the goals of the institution/agency/institution.

5. Determination of the Highest Diploma Value There Is No Clear Standard Benchmarks Due to Diversity Diplomas with Different Number of Subjects as Well as Explanation of High School Levels with Less Obvious Levels So That Can Result in Multi Interpretations

In the Tanah Laut Regent Regulation No. 6 of 2016 concerning the Appointment and Dismissal of Village Officials, it has not explained in detail the highest diploma scores, because each year there are differences in the number of subjects, moreover between high schools, vocational schools, and Madrasah Aliyah and Package $\mathrm{C}$ there are differences number of subjects and cannot be generalized.

6. Benchmark Competence of Village Apparatus Graduates Should Not Only Use Diploma Values, Because Diploma Values Do Not Necessarily
Prove That Village Devices Are Qualified and Have Competence in Carrying Out Their Duties in the Village Government

This is based on the assessment of the community who saw firsthand that in reality the value of a diploma does not absolutely guarantee that the appointed village apparatus is of high quality and able to carry out their duties in the administration of village government. Regulations should include relevant benchmarks in addition to diploma grades.

\section{Conclusions of External Factor Analysis (KAFE)}

Is a factor from outside the entity that incidentally is not directly involved in what is being studied and consists of 2 (two) points, namely threats and opportunities. This opportunity and threat will certainly provide data that must be included in a research journal so that it will produce a strategy to deal with it. Matters included in external factors are trends, culture, social politics, ideology, economy, and sources of capital, government regulations, technological developments, events that occur, and the environment.

\section{Opportunity}

a. An evaluation from the PMD Office related to the planned issuance of new regulations

Evaluation from related agencies is very important to know the extent of the implementation of the village apparatus selection. This moment is very appropriate to provide advice and input, especially the addition of work experience; competencies possessed, and detailed explanations related to diplomas owned by prospective village officials.

b. Many villagers are interested in working in the village office

With so many villagers interested in working in the village office, increasing the number of candidate village apparatus compositions varies from which level of education, gender, and graduate school or college. This is considered positive and benefits the village in choosing the best village apparatus among the best, as long as all the villagers get information on the selection and screening of village officials.

c. Increased public awareness to send their children to higher education

Job opportunities in villages that require higher education open the mindset of the local village community to send their children to a higher level. This has a positive impact on improving the quality of human resources in the village which will be an important factor in supporting increased village development.

d. Suggestions from various parties are related to consideration of work experience and skills in addition to the value of a diploma in determining the selection of candidates for village apparatus 
Various layers of society and related stakeholders suggest that in the selection of village officials also be considered as consideration for the escape of the candidate village apparatus, namely work experience and skills possessed as supporters of the value of a diploma. With this additional assessment factor, the village will get a quality village apparatus and is ready to work.

\section{Threat}

a. The seeds of unhealthy competition among fellow villagers who are interested in becoming candidates for the village apparatus due to limited employment

The statement of bad mouthing or dropping each other among fellow villagers who compete with each other to qualify as village officials. This is actually a small problem, but if left unchecked will have a major impact on the course of community life in the village.

b. Candidates who are accepted only qualify based on high diploma scores but do not necessarily have decent competencies

Human Resources from village communities only highlight the highest diploma scores, even though this is still not relevant to the implementation of village government tasks. Even though it is also necessary to pass village officials in order to consider their work experience and competencies.

c. There are still opportunities for nepotism in appointing families or supporters as village officials

There was a statement from the community stating that the village apparatus candidates who passed the selection all had family ties and were supporters of the village head in the village head election.

d. Interventions and approaches from other parties or those in power towards the independence of the village apparatus selection process and related parties

As stated by several informants, there were interventions carried out by several parties, namely individual members of the DPRD, officials, community leaders, or persons who were close in the circle of power.

\section{CONCLUSION}

The selection of village officials in the Village of Handil Babirik, Bumi Makmur Subdistrict and Tajau Pecah Village, Batu Ampar Subdistrict has basically proceeded according to the applicable regulations. It's just that there are some things that are not in accordance with existing regulations and expectations. The results of the evaluation also focus on 3 (three) aspects, namely village apparatus / human resources, organization, and implementing regulations. The results of the evaluation of the selection of village officials in the two villages are:

1. Village Staff/Human Resources

a. Weak administration at the village level due to inadequate human resources

b. The community's understanding of the decisions taken regarding the selection of village officials was better in Tajau Pecah Village than in Handil Babirik Village. This is due to various factors, namely the number of promising employment opportunities and the existence of sincere feelings of mutual respect

2. Organization

a. There are differences in interpreting the rules. This is due to understanding different regulations from stakeholders. For example, in relation to prospective village officials, they must first choose an empty formation at the time of receiving the candidate for the village of Tajau Pecah, while in Handil Village, Babirik will only be determined by a Decree of the Village Head. The stakeholders include the sub-district head, the village head, the screening team and selection committee. Actually, the appropriate mechanism is that the village apparatus candidates directly choose the formation of interest.

b. Lack of transparency of information on the selection and screening of village officials from the village head and the screening team to the local community This is due to the lack of communication between the two parties, the lack of compliance with regulations, and the desire to facilitate family / colleague / support breakouts as village officials.

c. The need for socialization related to regulations on screening and screening of village officials so that all parties know clearly.

3. Implementation Rules

The determination of the graduation selection has not accommodated the skills and competencies of the candidates through the relevant test methods, whereas this is important so that the village officials received are qualified in carrying out the tasks of the village administration.

\section{REFERENCES}

1. Atmosudirdjo, P. (1986). Dasar-Dasar Ilmu Administrasi. Jakarta: Ghalia Indonesia.

2. Gie, T. L. (1986). Administrasi Perkantoran. Yogyakarta: Nur Cahya.

3. Bryan, C., \& Louis, G. W. (1987). Manajemen Pembangunan Untuk Negara Berkembang. Jakarta: LP3ES. 
4. Mulyana, D. (2001). Metodelogi Penelitian Kualitatif: Paradigma Baru Ilmu Komunikasi dan Ilmu Sosial Lainnya. Bandung: PT Remaja Rosdakarya.

5. Hadi, S. (1995). Metodologi Research Jilid IV. Jogjakarta: Andi Offset.
6. Afifuddin., \& Ahmad, B. (2009). Metodologi Penelitian Kualitatif. Bandung: Pustaka Setia.

7. Indrawijaya, A. I. (1983). Perilaku Organisasi. Bandung: Sinar Baru. 